\title{
RE-DISSEMINATION OF NEWS AND PUBLIC DEBATE ON SOCIAL NETWORKS
}

\section{Redistribución de noticias y debate público en las redes sociales}

\author{
Javier Guallar, Jaume Suau, Carlos Ruiz-Caballero, Albert Sáez, and Pere Masip
}

Nota: Este artículo puede leerse traducido al español en:

http://www.elprofesionaldelainformacion.com/contenidos/2016/may/05_esp.pdf

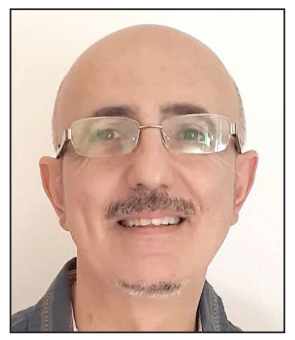

Javier Guallar holds a PhD in information and documentation, and is a professor with the Faculty of Library and Information Science at the University of Barcelona, Blanquerna School of Communication and International Relations at the Ramon Llull University, Information and Communication Studies at the Open University of Catalonia, and Communication at the International University of Catalonia. His main research interests are documentation in the media, digital journalism, sources of information, scientific publishing, and content curation. He has authored numerous articles and several books.

https://orcid.org/0000-0002-8601-3990

jguallar@gmail.com

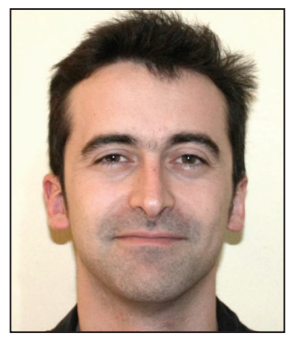

Jaume Suau holds a PhD in communication, and is a researcher at the Blanquerna School of Communication and International Relations at the Ramon Llull University. He is a member of the research group Digilab: media, strategy, and regulation. His main research interests are the effects of new digital technologies on society and journalistic practice. He is also project manager of the European-funded project Med media, aimed at improving journalism in North African and Middle Eastern countries.

http://orcid.org/0000-0003-4480-4441

jaumesm@blanquerna.url.edu

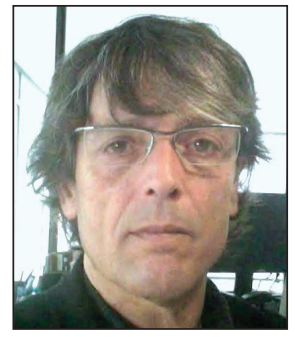

Carlos Ruiz-Caballero holds a PhD in journalism and is a professor at the Blanquerna School of Communication and International Relations at the Ramon Llull University. His main research interests are media convergence, digital journalism, and active audiences from the perspective of the ethics of communication. He was awarded the Josep Vallverdú 2014 essay award for the play The digitization of the other. He is the author of La agonía del cuarto poder, Prensa contra democracia (Trípodos, 2008), and Ética de la audiencia (Grafite, 2003). He has participated in several national research projects and has published in journals such as International journal of press and politics. He is a member of the Council of Information of Catalonia.

https://orcid.org/0000-0002-1395-2145

carlesrc@blanquerna.url.edu

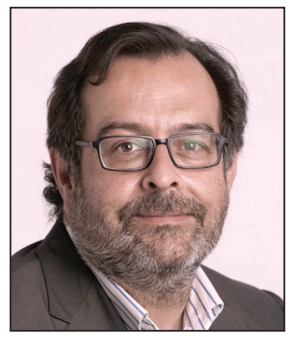

Albert Sáez is professor of the Blanquerna School of Communication and International Relations at the Ramon Llull University. He teaches in matters related to the sociology of communication, journalism, and technological innovation. He is co-director of the Master in political and social communication. In 2014 he won the Joan Fuster Essay Award with the work El periodisme després de Twitter. He investigates issues related to technological innovation and its impact on the practice of journalism and the organization of society. He is a member of the research group Digilab: strategy, media, and regulation. In the professional field he is now deputy director of the newspaper El periódico de Catalunya.

https://orcid.org/0000-0003-2499-7207 


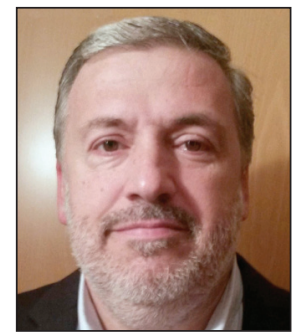

Pere Masip is a professor of journalism at the Blanquerna School of Communication and International Relations at the Ramon Llull University, where he also gained his PhD in journalism. He is the main researcher of the research group Digilab: media, strategy and regulation. His main research interests are media convergence, digital journalism, and the impact of technology on journalistic and communication practices. He has participated in several national and international projects. $\mathrm{He}$ is currently coordinating a research project funded by the Spanish Ministry of Economy and Competitiveness entitled Active audiences and agenda-setting in the digital public sphere. He is the author of numerous articles and books.

https://orcid.org/0000-0002-8231-0824

peremm@blanquerna.url.edu

Universitat Ramon Llull, Facultat de Comunicació i Relacions Internacionals Blanquerna Plaça Joan Coromines, s/n. 08001 Barcelona, España

\begin{abstract}
The results of a qualitative research study based on 12 focus groups with a total of 106 people about the role of social networks in the consumption of current information are presented. We inquired about the motivation of citizens to interact with the news on social networks, and if they consider them appropriate spaces for public debate. Some findings of this study suggest that social networks are seen as an adequate space to share news and information on matters of public interest; to extend the agenda of topics that focus on the interests of users by allowing them access to topics often silenced in their usual media; and finally, social networks are viewed as more suitable for opinions, rather than public debate.
\end{abstract}

\title{
Keywords
}

Online journalism; Social Networks; Active audiences; News dissemination; News consumption; Public debate; Focus groups.

\section{Resumen}

Se presentan los resultados de una investigación cualitativa basada en la realización de 12 grupos de discusión con un total de 106 personas sobre el papel que tienen las redes sociales en el consumo de información de actualidad. Se ha indagado acerca de la motivación de los ciudadanos para interactuar con las noticias en las redes sociales, y sobre si éstos las consideran espacios adecuados para el debate público. Algunas conclusiones de este estudio apuntan a que las redes sociales son vistas como un espacio adecuado para compartir noticias e informaciones sobre asuntos de interés público, amplían la agenda de temas que centran el interés de los usuarios y les permiten acceder a temas habitualmente silenciados en sus medios de consulta habituales; y son más aptas para la opinión que para el debate público.

\section{Palabras clave}

Periodismo digital; Redes sociales; Audiencias activas; Distribución de noticias; Consumo de noticias; Debate público; Grupos de discusión.

Guallar, Javier; Suau, Jaume; Ruiz-Caballero, Carlos; Sáez, Albert; Masip, Pere (2016). "Re-dissemination of news and public debate on social networks". El profesional de la información, v. 25, n. 3, pp. 358-366.

http://dx.doi.org/10.3145/epi.2016.may.05

\section{Introduction}

Within the current hybrid media system, in which the "old" and "new" media coexist (Chadwick, 2013), the role of social networks in the consumption of news has become increasingly important in recent years, thereby constituting a public sphere for the debate and formulation of public opinion (Papacharissi, 2010) or, in our view, becoming included in and widening the pre-existing public sphere. Various scholars have highlighted the importance and the transformational potential of user interactions in social networks in the traditional news cycle, when exchanging or discussing contents related to news or public affairs (Nielsen; Schrøder, 2014; Almgren; Olsson, 2015; Newman; Dutton; Blank, 2012). These new dynamics, arising from users who share, recommend, or send news material to their contacts through private messages in social networks, expands the scope of the public sphere in which ordinary citizens gain a larger role (Singer et al. 2011; Papacharissi, 2015; Klinger; Svensson, 2015), jeopardizing the traditional hegemony of the journalists and media as gatekeepers of public affairs (Suau, 2015; Suau; Masip, 2015).

Previous research has focused on the effects of the redistribution of content on social networking like Facebook or Twitter (Singer, 2014; Coddington; Holton, 2014; Vos; Heinderyckx, 2015). Most of the previous studies have used quantitative methodologies and have focused on analyzing the type of news shared, as well as the social network used (Bastos, 2015). According to these studies, Facebook is more widely used to share material relating to entertainment, while Twitter is more closely linked to current affairs or hard news (Newman, 2011), and the users sharing material on Twitter are older than those sharing on Facebook 
(Newman; Levy, 2014). Some authors have also highlighted the perception of Twitter as elitist (Engesser; Humpretch, 2015), a social network in which journalists and politicians are particularly active. In contrast, Facebook is used more by ordinary citizens to share material with their contacts or friends (Almgren; Olsson, 2015).

In comparison with other fields of study related to social networks, the users' motivations for sharing or debating in online media have received little attention. The few existing studies, most of which are quantitative, indicate personal motivation or entertainment as the main reasons leading users to participate in the redistribution of news or in the debate on social networks, as opposed to an active motivation to produce or enhance the journalistic content, in a similar way to that which occurs with comments in the news (Baden; Springer, 2014; Larsson, 2014; Paskin, 2010; Heise et al., 2013). The lack of interest in an in-depth analysis of citizens' attitudes and motivations for publishing, redistributing content, and entering into debate on social networks follows the traditional trend in communication research of undervaluing the perceptions of the public, in contrast with the large amount of research devoted to analyzing the newspaper messages or the behavior of newsrooms and journalists (Van-der-Wurf; Schoenbach, 2014; SlavtchevaPetkova, 2016). The previous studies on social networks tend to follow what we could call a certain "methodological convenience", focusing almost exclusively on Twitter, which provides open data, allowing researchers to analyze the flow of messages and the construction of a network of tweets, re-tweets, mentions and hashtags (Paulussen; Harder, 2014; D’Heer; Verdegem, 2014).

\section{Objectives and methodology}

This article forms part of a broader research project ${ }^{1}$ with the general aim of studying the role of active audiences (Masip et al., 2015b) in the current hybrid media system. Specifically, it has three main objectives: (a) to achieve a greater understanding of the role played by social networks in the consumption of news; b) to determine citizens' reasons for interacting with the news in social networks, and (c) to ascertain whether citizens regard social networks as suitable spaces for public debate.

To meet these objectives, a qualitative approach was taken, based on focus groups, which were a follow-up to quantitative research previously undertaken (Masip et al., 2015a; 2015b). The qualitative technique of focus groups is aimed at stimulating participants' reflection through group conversation (Morgan, 1997). Participants may express their "latent thoughts" (Hansen et al., 1998) and show how they construct their own personal meaning on public affairs (Gamson, 1992).

In December 2014, 12 focus groups were carried out in Barcelona, involving a total of 106 individuals. This number of groups was similar to those used in studies with similar characteristics (Coleman; Anthony; Morrison, 2009; Couldry; Livingstone; Markham, 2007). All the focus groups were recorded in audio and video to facilitate the subsequent transcription of conversations.
Research using focus groups makes it difficult to reach conclusions which can be generalized. With the aim of minimizing the problems arising from their representativeness, Morgan (1997) recommends selecting participants through theoretically motivated sampling. Thus, in line with other research (Schrøder; Phillips, 2007; Coleman; Anthony; Morrison, 2009), participants were selected by taking into account criteria such as age, sex, and level of education. With regard to the latter, 43 of the participants were not university-educated, whereas the other 63 had at least a 3-year university degree. Additionally, two extra selection criteria were added as they were considered to be relevant to the objectives of the research: civic engagement and media engagement.

It was broadly established that, to meet the requirement of civic engagement, the individuals had to be regularly involved in, members of, or linked to a political party, trade union, NGO, cultural association, or social movement. Thus, 43 people with "civic engagement" were recruited, while the remaining 63 were not involved in any association of this kind.

Lastly, in the process of recruitment of participants, there were three predefined levels of media engagement:

\begin{tabular}{|l|l|}
\hline $\begin{array}{l}\text { High media } \\
\text { engagement }\end{array}$ & $\begin{array}{l}\text { People who read the news every day of the week } \\
\text { using one of the two media (printed or online), } \\
\text { and, at least two days a week, read news in the } \\
\text { other medium (printed or online) that they do not } \\
\text { use on a daily basis. }\end{array}$ \\
\hline $\begin{array}{l}\text { Medium media } \\
\text { engagement }\end{array}$ & $\begin{array}{l}\text { People who read the news in the printed media or } \\
\text { online more often than once a week, but less than } \\
\text { six times per week, or who read the news online } \\
\text { more than once a week but less than six times per } \\
\text { week and at least once per week in the printed } \\
\text { media. }\end{array}$ \\
\hline $\begin{array}{l}\text { Low media } \\
\text { engagement }\end{array}$ & $\begin{array}{l}\text { People who read the news online once a week } \\
\text { (irrespective of how often they read news in the } \\
\text { printed media). }\end{array}$ \\
\hline
\end{tabular}

In the focus groups that were formed, there were ultimately 37 people with a high level of media engagement, 46 with a medium level and 23 with a low level. Since one of the objectives of the research was to find out the citizens' motivations and the use they make of the participating mechanisms of digital media and of social networks for news purposes, in the criteria for defining the three levels of media engagement, the consumption of print news was taken into account, but the consumption of online news was the key focus. The use of television as a source of news was not included as a variable because this is not a discriminatory criterion, since $71 \%$ of Spaniards claim to watch the news on television on a daily basis (CIS, 2013).

Lastly, with regard to the specific configuration of the groups, each had participants who shared a common characteristic from the three selection criteria we have described and a balance was maintained across the groups between sex, age, and the other criteria. Thus, there were two focus groups whose participants did not have a university education, two that had a university education, two groups with civic engagement, two without civic engagement, one 
with a high media engagement, one with a low media engagement and two with a medium media engagement.

\section{Findings}

Most of the participants in the focus groups stated that they received content about public affairs through their social networks on a more or less regular basis (several times a day). We use "public affairs" to indicate those topics defined by Mouffe $(1997 ; 2005)$ as "political", a concept that encompasses topics beyond the strictly political and includes subjects that concern or affect citizens but are outside the daily political debate or the struggle between political parties. The following focus group conversations reflected the general trend of a high reception of content related to public affairs:

MG36: Oh yes... several times a day...yes

MR63: Yes, yes, all the time...

JLM67: I read more than I share.

JMA60: Yes, me too.

(all): Every day...

GC23: Constantly... though I might look at it later or I might see the picture and think "what a load of rubbish"

MB23: Yes, you look at a few lines and that's it...

The extracts above and other comments made in the focus groups highlight the large number of formats in which citizens received content on the "political": links, photographs, videos, text, and image compositions (memes), etc. However, the majority of the participants stated that most of the content they received was links to news produced by media or by journalists. This is in line with the quantitative data from previous studies, in which it has been noted that access to news is the second motivation for the use of social networks, after relationships with friends and acquaintances (Masip et al., 2015b, p. 366).

\section{Participants expressed greater confiden-} ce about the content found in social networks if the content had been previously published by media

The participants, especially those older than 40, expressed greater confidence about the content found in social networks if the content had been previously published by mainstream outlets. These participants still respected a certain hierarchy of the media with regard to the content generated by third parties in social networks, as shown in the following comments:

BA43: [what do you read on social networks?] A little bit of everything, newspapers in general and then specific journalists, Julia Otero, for example. I like the way she talks a lot, although I don't like some of her ideas; I like Ana Pastor, for example, how she discusses the news, I follow her.

JA70: I read The vanguardia, because it's like a habit now. It's the only medium I follow on an ongoing basis. What we are talking about here, links, I don't like them very much, I need a degree of reliability that there is some truth in it, otherwise... it's just spreading rumors and I dislike that...

\section{Selective exposure in social networks}

In the focus groups, a general view was identified in support of social networks because they allow people to access news outside their usual subjects of interest or that would otherwise go unnoticed, since it does not form part of the media selection that the person usually consumes. Social networks, in this way, could break with the pre-established dynamics of selective exposure of individuals (Prior, 2007), as acknowledged by the participants themselves in the focus groups:

LS24: Yes, I think so, because you have a lot of people on Facebook. Not all of them think differently, that is to say, not all of them think the same. There are a lot of different things and yes, they offer you something new. The good thing about it is that, when you see a piece of news, other items are always displayed underneath and you end up turning your attention to a lot more things because you look at what people are saying to each other.

ABF53: There is always something that is posted that you end up looking at and thinking: Wow, isn't that amazing? Because you haven't seen it on TV, nor are they talking about it in the media.

ILG57: Yes, especially international news, they send you things where you say: I don't normally read this.

\section{Social networks allow people to access} news outside their usual subjects of interest or that would otherwise go unnoticed

Similarly, participants noted that pieces of news reached them through friends in social networks, and that they were not from their usual sources of information, which included news that directly challenged their points of view and/or ideological positions. Although the data obtained in other studies (Masip et al., 2015b) has shown a low rate of consumption of this type of content of the total ("only" $7 \%$ of the news received through social networks is from media that have a different ideological stance to their own as opposed to $77 \%$ from media they usually consult), this fact was significant in itself from a quantitative point of view and is even more so because of how it was perceived by participants in the focus groups. As several scholars have highlighted (Mouffe, 2013; Sustein, 2003; Barber, 2006), a democracy requires, for its proper development, the creation of spaces in which citizens may come into contact with visions of the political world that challenge their own. Social networks, as is reflected in the following extracts from the focus groups, seem to fulfil this function, in some cases creating citizen discussion and debate on public affairs, and differing points of view, thus potentially promoting pluralism: 
XB23: On Facebook there are some pages people follow that publish information which is contrary to or approached from a different point of view from my own.

AC20: I have a friend who isn't that different to me, but who often sends me news items that don't affect me, but go against my ideas and sometimes I counterattack and send him others back.

MJ34: They give you another point of view. It is always good to be aware of both sides of the coin and listen to everyone, because if you only believe one side maybe you are missing the other; it is good to know your own view and everyone else's.

\section{Social networks create citizen discussion} and debate on public affairs, and differing points of view, thus potentially promoting pluralism

\section{Motivations}

The examples above display some of the reasons why citizens share information on social networks. Participants expressed a wide range of motivations for interacting with current affairs news, sharing news items, and discussing them.

- The need to share a news items and discuss them with friends or acquaintances on social networks:

FA64: A need to share and to ask your friends' opinions.

OV40: If I come across something undisclosed and I'm the first to find it, then I post it.

- The belief that the story is important and that it is worth passing on to followers or contacts:

BPB25: When there is something important. Then you think you should give it a bit of publicity.

GC23: Things you think really define you, like, this is exactly what I think and this guy explains it very well I'm not good at writing myself - and I publish it.

JC49: Basically things that spark my interest; they are not necessarily negative, it might be something I reaIly like and I also want to share.

- A special interest in the subject:

GL58: Because the subject concerns you; so maybe you tell your friends, people who are on Facebook, to find out their views about a topic that you are concerned about and interested in.

- A method of ideological proselytism:

IE26: Due to political affiliation I post things that have been done or in which l've taken part or that have been done by my party and that sometimes don't make the press, or also the odd article of my own.

- A reaction of protest or of indignation to a news story. This is one of the most frequent motivations:

CCM29: Protest.

FRB20: Indignation.
JMA60: Indignation...

- The dissemination of topics not usually published in the conventional media:

AC33: It tends to be news that draws attention to things the traditional media make invisible; it tends to be news of a critical nature such as cases of corruption, etc. Sometimes when I share, I copy a bit of the article.

In short, a strong connection was found between the individual and the content that they shared or commented on. This was the main motivation, which was expressed in differing ways: because of interest in the news, because the news is important in itself, because it sparks a reaction of indignation or anger, because it is thought that the news has a low profile or is little-known and that it is pretty much "a first", because there is a strong identification with it, due to ideological affiliation, and so on. Whereas the sole motivation given in which the importance of the content was not openly expressed was pure relational activity: the need to share with friends. This identification between content and user implies that the selection of the content and the attitude towards it defines the individual socially. We could sum up this connection in one sentence: tell me what you share and I'll tell you who you are (socially).

\section{A strong connection was found between the individual and the content that they shared or commented on social net- works}

Therefore, audiences interacted with the news items according to their interest, concern, emotion - their connection, in short - to the content. And this happened in a social networking environment where their interlocutors were usually nearby and close to them, or at least more so than in other environments, such as the spaces provided by the media for participation. Here the interlocutors were friends and acquaintances (Facebook) or followers (Twitter). In this environment, despite the specific difficulties that are discussed in the next section, they were sharing and commenting on current affairs, on what interested them, concerned them or motivated them.

\section{Social networks as a space for debate}

As previously noted, the participants in the focus groups held differing views on the suitability of social networks as a place for debate and exchange of views. Some participants also referred to specific or differentiated behavior between Facebook and Twitter. They pointed out that Facebook is a relational space where family and acquaintances meet, whereas on Twitter, due to its nature as a public publishing system, the contents can be seen by everyone.

There is a reasonable consensus that social networks are more appropriate for debate and exchange of views than other spaces, such as the spaces provided by the media to comment on news (Suau, 2015; Suau; Masip, 2015). However, social networks are not presented as ideal contexts for 
debate, according to comments made in the focus groups. Facebook is preferred because "it is more suitable for chatting, saying hello, or arranging to meet" (BPB25), while Twitter may facilitate debate. Some people regularly entered into discussion specifically in the media's profiles on social networking sites like Twitter:

BS57: When I want to have a discussion, I go to Twitter to whatever program it is, for example Catalunya Ràdio's El suplement del matí, also the radio station Cadena SER, and Julia Otero's Twitter; that's where the debate is, where you also realize that people will respond to you.

One participant raised an interesting point, making a distinction between commenting and discussing:

XB23: On Twitter you can tweet, you make comments and it's not a debate, you're expressing your position. They aren't debates, in the sense of a conversation where points of view are exchanged, rather, you comment on a piece of news or you retweet, whereas to start a debate, an exchange of ideas, I'm more inclined to do it in person with whoever I want to, and not with a stranger whose opinion doesn't matter to me.

Twitter was, therefore, regarded as a suitable place to express a point of view, but not for a debate. On the whole, participants recognized that the right conditions for debate were not always present in social networks:

RR23: Sometimes you see a news item and you say, I feel like making a comment and you do, and then someone answers you and you spark off a debate, and they can sometimes get awkward [all laugh], because you sometimes come across some idiot who makes you say, bloody hell, I am going to make my Facebook account even more private.

This study confirms the paradox, which was demonstrated in previous research, that users distrust the media, but that, when sharing news on social networks, they are their main reference points

As is the case with comments on the news (Ruiz et al., 2013), the lack of courtesy and good manners could easily degenerate into confrontation and even insults:

JC49: I participate as long as everyone behaves courteously; when that is lost, I'm not interested anymore and I'm out of there. Yes, when people start insulting each other and that kind of thing, you say look, this is where I leave you, I don't want to get into this.

LS24: That's why I don't make any comments, I don't fancy getting into arguments and, well, when you express the opposite idea to what people think, then they all turn on you and it doesn't pay off... it's not worth it for me.

RR27: Because there is always someone who oversteps the mark and then someone else who goes even further.
Because of the differences between Twitter and Facebook, people were even more wary about entering into debates on Facebook than on Twitter. The "friendship" that linked the members of a community on Facebook led, for some, to a fear of "losing friends" because of the tone or the subject of some debates. This unease carried over into the offline environment:

CF47: Well, like he said, on the same lines, that by being honest you lose friendships; so, you're politically correct - at least I am - depending on the comment, depending on the debate, you leave it as soon as you see things start to... If I express an opinion, if it's when I'm at a family get together or with friends... I don't give it, because if we are going to talk about politics or whatever, everyone will give their own view, what they feel, their ideology, and that's not going to change, it would be like changing religion.

IE26: On Facebook you have family, people with whom you don't want to get into debate, but on Twitter I don't like to get into controversy either because it goes down in writing and that's off-putting.

The role of gatekeeper in the hybrid media system is distributed consecutively between the media when they decide to publish the content

As we have noted above, social networks enable users to access a wider range of sources, some of which have differing ideologies. However, this does not always lead to dialogue and social networks are not perceived as suitable spaces for public debate.

Debate on certain subjects, such as politics or ideology, was also noted to be more difficult by participants. These were subjects that were seen as liable to produce more confrontation. There was also greater caution regarding privacy and the public exposure of one's political ideas or stances. This was in contrast to other subjects that lent themselves more to "positive" discussions, such as health or spirituality.

MP53: But things that are positive, like matters of health, natural remedies, spirituality... I don't want to get into talking about politics because the discussions don't lead anywhere, because everyone has their own beliefs, and nor do I want people to know my political ideas to be on the safe side. It is something public that anyone can see, so I keep them to myself, as anyone can see Facebook and we don't know who is behind Facebook, do we?

In this regard, a specific topic in the current political scene was mentioned by a number of participants--the issue of Catalonia's independence.

JRF65: The subject of the independence of Catalunya has given rise to a situation in a group of friends where, for example, in WhatsApp, a few say: Come on, let's create another group because I've got a "pro" or "anti" sentiment. And so then they have split up. 


\section{Discussion and conclusions}

In most academic and professional discussions the media and social networks are regarded as alternative channels which are used by citizens to obtain news. However, the findings of this study suggest that there is an ongoing interaction between the two according to the users' behavior. $A$ qualitative approach enabled us to identify some of the mechanisms that characterize this ongoing interaction in the behavior of audiences.

1) Social networks were viewed by users as an appropriate space to share news and views on public affairs. In line with previous studies carried out in other countries (Nielsen; Schroder, 2014; Almgren; Olsson, 2015; Newman; Dutton; Blank, 2012), the majority of the participants stated that they received content through this channel several times a day.

\section{Social networks appeared to be more of a space for opinion rather than debate, particularly for disseminating people's own views}

2) The content that was shared by participants had very varied formats (from links to memes), but the content normally came from items that had been published by the media, who have maintained citizens' trust as the main source of information. This study confirms the paradox, which was demonstrated in previous research (Suau; Masip, 2015), that users distrust the media, but that, when sharing news on social networks, they are their main reference points. Therefore, there was a double-filter for our participants in determining their confidence in the content: that of their friends in the social networks who "shared" the content, and that of media that originally published the content. This observation would merit a more in-depth examination, but points to the possibility that the role of gatekeeper (Singer, 2014) in the hybrid media system is distributed consecutively between the media (when they decide to publish the content) and the users' contacts in the networks (when they decide to "share" it). This situation would downplay the importance of the decisions made by the media and would give a greater role to the decisions of the users themselves when setting up their network of relationships in the media. This hypothesis would entail a fragmentation of the effects of the media and would confirm the hybrid nature of the new media environment (Chadwick, 2013).

3) The news contents shared in social networks broadened the range of issues and led them to consider points of view and approaches that were different from their own, strengthening the deliberative democracy (Mouffe, 2013). If this trend is confirmed in quantitative studies, it would require a rethink of the debate about the homogenizing force of social networks that are structured on the users' affinities. The users' responses seemed to indicate that the access to media content through social networks widened the range of editorial approaches that they consumed. They no longer only read one newspaper, listened to one radio station, or watched one television channel, but now also came into contact with items that aroused the interest of their contacts on social networks. Future studies would need to explore the degree of affinity between what is being shared and the ideology of the users.

4) Social networks provided users with access to topics which are often suppressed in the media where they regularly read the news. This conclusion, derived from the focus groups, opens up a very interesting debate on the silences produced by the actions of the media as a gatekeeper. While citizens only consumed information from traditional media, the "silence" was perceived only in their individual experiences as a consumer. So, whatever "their paper" didn't tell them was silenced. The dissemination of information via social networks caused a mirror effect so that the silences of certain media become more evident. Curiously, users did not attribute this break to the plurality of editorial policies, but to the contribution of the emancipated users, an aspect that had not been sufficiently highlighted in previous research (Singer, 2014; Coddington; Holton, 2014; Vos, 2015).

5) Social networks appeared to be more of a space for opinion rather than debate, particularly for disseminating people's own views which were expressed through the use of links to news that mainly reflected their own beliefs.

6) Lastly, it has been noted that users are somewhat wary of expressing themselves freely on certain issues, especially political issues, to friends and family (Facebook) or strangers (Twitter). The "spiral of silence" was also observed in the comments of the participants, where silence was preferred to social isolation, in this case, in social networks.

\section{Users are somewhat wary of expressing themselves freely on certain issues, es- pecially political ones, to friends and fa- mily (Facebook) or strangers (Twitter)}

\section{Note}

1. This research forms part of the projects funded by the Ministry of Economy and Competitiveness, references: CSO2012-39518-C04-01 and CSO2015-64955-C4-1-R

\section{References}

Almgren, Susanne M.; Olsson, Tobias (2015). "Lets get them involved... to some extent: Analyzing online news participation". Social media + society, v. 1, n. 2. http://dx.doi.org/10.1177/2056305115621934

Baden, Christian; Springer, Nina (2014). “Com(ple)menting the news on the financial crisis: The contribution of news users' commentary to the diversity of viewpoints in the public debate". European journal of communication, v. 29, n. 5, pp. 529-548.

http://dx.doi.org/10.1177/0267323114538724 
Barber, Benjamin (2006). “¿Hasta qué punto son democráticas las nuevas tecnologías de la telecomunicación?". IDP. Revista de internet, derecho y política, n. 3.

http://www.uoc.edu/idp/3/dt/esp/barber.html

Bastos, Marco-Toledo (2015). "Shares, pins, and tweets. News readership from daily papers to social media". Journalism studies, v. 16, n. 3, pp. 305-325.

http://dx.doi.org/10.1080/1461670x.2014.891857

Chadwick, Andrew (2013). The hybrid media system: Politics and power. Oxford: Oxford University Press. ISBN: 978 0199759484

CIS (2013). Barómetro de marzo. Distribuciones marginales. Madrid: CIS.

http://www.cis.es/cis/export/sites/default/-Archivos/ Marginales/2980_2999/2981/Es2981.pdf

Coddington, Mark; Holton, Avery E. (2014). "When the gates swing open: Examining network gatekeeping in a social media setting". Mass communication and society, v. 17, n. 2, pp. 236-257.

http://dx.doi.org/10.1080/15205436.2013.779717

Coleman, Stephen; Anthony, Scoth; Morrison, David (2009). Public trust in the news: A constructivist study of the social life of the news. Oxford: Reuters Institute. ISBN: 978 0955888953

Couldry, Nick; Livingstone, Sonia; Markham, Tim (2007). Media consumption and public engagement. New York: Palgrave Macmillan. ISBN: 9781403985347

D’Heer, Evelien; Verdegem, Pieter (2014). “Conversations about the elections on Twitter: Towards a structural understanding of Twitter's relation with the political and the media field". European journal of communication, v. 29, n. 6, pp. 720-734.

https://eveliendh.files.wordpress.com/2014/10/preprintversion-ejc-conversations-about-the-elections-on-twitter.pdf http://dx.doi.org/10.1177/0267323114544866

Engesser, Sven; Humprecht, Edda (2015). "Frequency or skiIlfulness". Journalism studies, v. 16, n. 4, pp. 513-529.

http://dx.doi.org/10.1080/1461670x.2014.939849

Gamson, William (1992). Talking politics. New York: Cambridge University Press. ISBN: 9780521436793

Hansen, Anders; Cottle, Simon; Negrine, Ralph; Newbold, Chris (1998). Mass communication research methods. New York: Palgrave Macmillan. ISBN: 978033367106

Heise, Nele; Loosen, Wiebke; Reimer, Julius; Schmidt, JanHinrik (2013). "Including the audience". Journalism studies, v. 15 , n. 4 , pp. $411-430$.

http://dx.doi.org/10.1080/1461670x.2013.831232

Klinger, Ulrike; Svensson, Jakob (2015). "The emergence of network media logic in political communication: A theoretical approach". New media \& society, v. 17, n. 8, pp. 1241 1257.

http://dx.doi.org/10.1177/1461444814522952

Larsson, Sofia (2014). "Battling mainstream media, commentators and organized debaters. Experiences from citi- zens' online opinion writing in Sweden". Nordicom review, v. 35 , n. 2, pp. 77-89.

http://nordicom.statsbiblioteket.dk/ncom/files/32830679/ nordicom_review_35_2014_2_pp._77_89.pdf

Masip, Pere; Guallar, Javier; Peralta, Miquel; Ruiz-CabaIlero, Carlos; Suau, Jaume (2015a). "Active audiences and journalism: Involved citizens or motivated consumers?". Brazilian journalism research, v. 11, n. 1, pp. 234-255.

http://bjr.sbpjor.org.br/bjr/article/view/815

Masip, Pere; Guallar, Javier; Suau, Jaume; Ruiz-Caballero, Carlos; Peralta, Miquel (2015b). "News and social networks: audience behavior". El profesional de la información, v. 24, n. 4 , pp. 363-370.

http://dx.doi.org/10.3145/epi.2015.jul.02

Morgan, David (1997). Focus groups as qualitative research. London: Sage Publications. ISBN: 9780761903437

Mouffe, Chantal (1997). The return of the political. London: Verso. ISBN: 9780860916512

Mouffe, Chantal (2005). On the political. Abingdon and New York: Routledge, 160 pp. ISBN: 9780415305211

Mouffe, Chantal (2013). Agonistics. London: Verso. ISBN: 9781781681039

Newman, Nic (2011). Mainstream media and the distribution of news in the age of social discovery. Reuters Institute for the Study of Journalism.

https://reutersinstitute.politics.ox.ac.uk/publication/ mainstream-media-and-distribution-news-age-social-discovery

Newman, Nic; Dutton, William H.; Blank, Grant (2012). "Social media in the changing ecology of news: The fourth and fifth estate in Britain". International journal of internet science, v. 7, n. 1.

http://www.ijis.net/ijis7_1/ijis7_1_newman_et_al_pre.html http://dx.doi.org/10.2139/ssrn.1826647

Newman, Nic; Levy, David A. (eds.) (2014). Reuters Institute Digital News Report: 2014. Tracking the future of news. Oxford: Reuters Institute for the Study of Journalism.

https://reutersinstitute.politics.ox.ac.uk/sites/default/files/ Reuters\%20Institute\%20Digital\%20News\%20Report\%20 2014.pdf

Nielsen, Rasmus K.; Schrøder, Kim C. (2014). "The relative importance of social media for accessing, finding, and engaging with news". Digital journalism, v. 2, n. 4, pp. 472-489. http://dx.doi.org/10.1080/21670811.2013.872420

Papacharissi, Zizi A. (2010). A private sphere. Democracy in a digital age. Cambridge: Polity Press. ISBN: 97807456 45247

Papacharissi, Zizi A. (2015). "Toward new journalism(s): Affective news, hybridity, and liminal spaces". Journalism studies, v. 16, n. 1, pp. 27-40.

http://dx.doi.org/10.1080/1461670x.2014.890328

Paskin, Danny (2010). "Say what? An analysis of reader comments in bestselling American newspapers". The journal of international communication, v. 16, n. 2, pp. 67-83. http://dx.doi.org/10.1080/13216597.2010.9674769 
Paulussen, Steve; Harder, Raymomd A. (2014). "Social media references in newspapers. Facebook, Twitter and YouTube as sources in newspaper journalism". Journalism practice, v. 8, n. 5, pp. 542-551.

http://dx.doi.org/10.1080/17512786.2014.894327

Prior, Markus (2007). Post-broadcast democracy. How media choice increases inequality in political involvement and polarizes elections. Cambridge: Cambridge University Press. ISBN: 9780521675338

Ruiz-Caballero, Carlos; Domingo, David; Micó, Josep-Lluís; Díaz-Noci, Javier; Masip, Pere; Meso, Koldo (2011). "Public sphere 2.0? The democratic qualities of citizen debates in online newspapers". The international journal of press/politics, v. 16, n.4, pp. 463-487.

http://dx.doi.org/10.1177/1940161211415849

Schrøder, Kim-Christian; Phillips, Louise (2007). "Complexifying media power: A study of the interplay between media and audience discourses on politics". Media, culture \& society, v. 29, n. 6, pp. 890-915.

http://dx.doi.org/10.1177/0163443707081693

Singer, Jane B. (2014). "User-generated visibility: Secondary gatekeeping in a shared media space". New media \& society, v. 16, n. 1 , pp. 55-73

http://openaccess.city.ac.uk/3445/

http://dx.doi.org/10.1177/1461444813477833

Singer, Jane B.; Domingo, David; Heinonen, Ari; Hermida, Alfred; Paulussen Steve; Quandt, Thorsten; Reich, Zvi; Vu- jnovic, Marina (2011). Participatory journalism. Guarding open gates at online newspapers. Malden, MA: Willey-Blackwell, 240 p. ISBN: 9781444332261

Slavtcheva-Petkova, Vera (2016). "We are not fools: Online news commentators' perceptions of real and ideal journalism". The international journal of press/politics, v. 21, n. 1, pp. 68-87.

http://dx.doi.org/10.1177/1940161215612203

Suau, Jaume (2015). Citizens and online media participation. Universidad Ramon Llull. Tesis doctoral. http://www.tesisenred.net/handle/10803/289347

Suau, Jaume; Masip, Pere (2015). "To participate in what? Contextualising online participation through citizens' discourses of public and media engagement. Comparative results London-Barcelona". En: The Future of Journalism Conference: Risks, Threats and Opportunities, Cardiff, 10-11 September.

Sustein, Cass R. (2003). República.com. Internet, democracia y libertad. Barcelona: Paidós. ISBN: 97884449313844

Van-der-Wurff, Richard; Schoenbach, Klaus (2014). "Civic and citizen demands of news media and journalists: What does the audience expect from good journalism?". Journalism \& mass communication quarterly, v. 91, n. 3, pp. 433-451. http://dx.doi.org/10.1177/1077699014538974

Vos, Tim P.; Heinderyckx, François (eds.). (2015). Gatekeeping in transition. New York: Routledge Press. ISBN: 978 0415731614

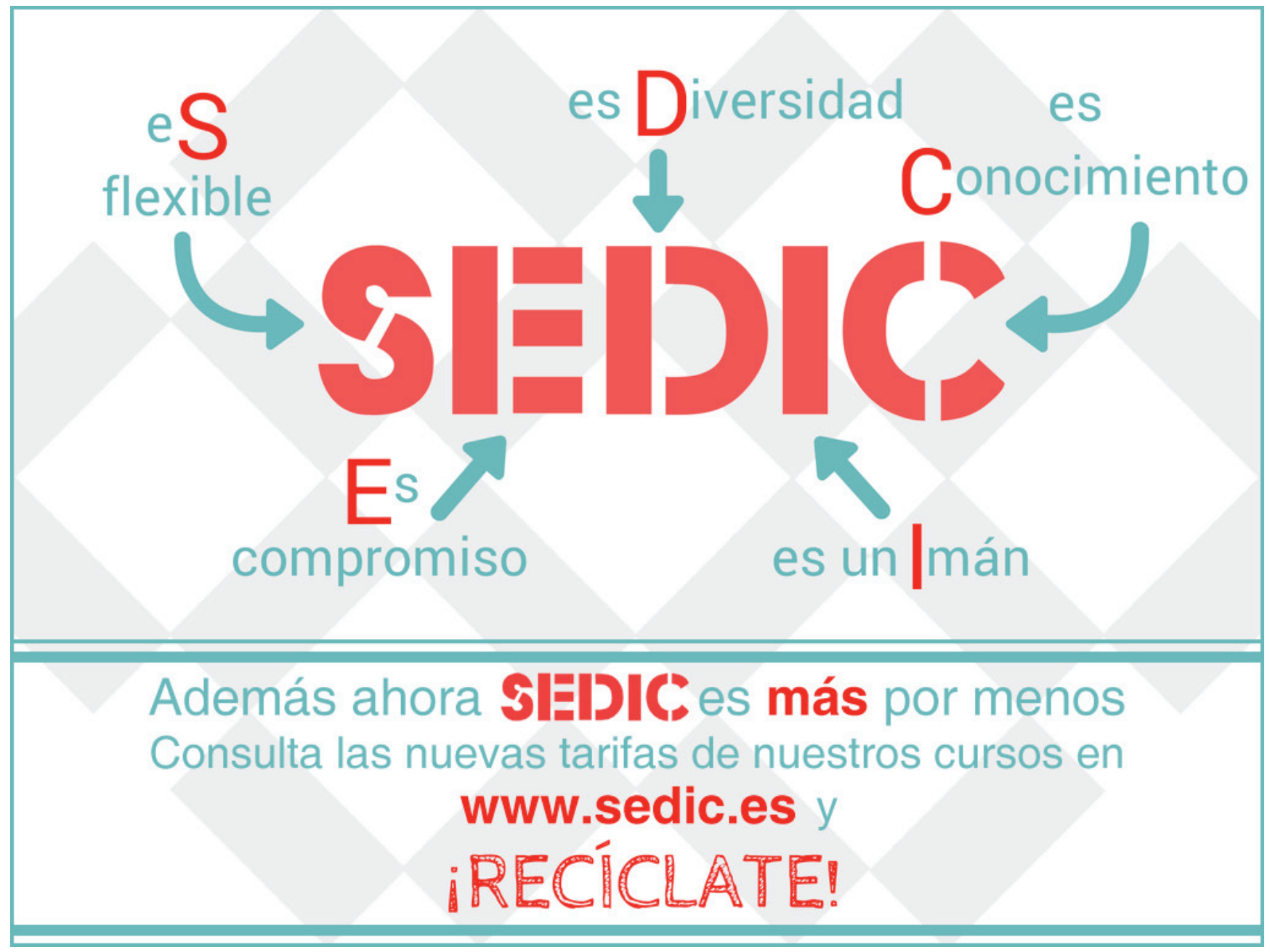

